\title{
Environmental Impact of River Dredging in Arctic Alaska (1981-89)
}

\author{
H. JESSE WALKER ${ }^{1}$
}

(Received 2 March 1993; accepted in revised form 3 January 1994)

\begin{abstract}
Economic and social development in northern Alaska during the past 25 years has created great demands for sand and gravel Although this resource is available on some beaches, riverbeds, barrier islands, beach ridges, and alluvial fans, surficial mining often results in undesirable environmental modification in this permafrost-dominated environment and has led to restrictions on extraction.

In 1981, for the first time, sand and gravel were transferred directly from the thalweg portion of a river to the tundra surface by a transportable suction dredge at Nuiqut in the Colville River delta, Alaska. The $400000 \mathrm{~m}^{3}$ of sand and gravel extracted were sufficient to construct a runway and create a stockpile for village use.

This procedure has been used in two other rivers (the Meade and Kokolik), three lagoons (Wainwright, Kaktovik, and Barrow), and two lakes (Atqasuk and Barrow). Profiling through 1989 shows that infilling of the dredged channels is a variable process.

Key words: Alaska, North Slope Borough, Colville River, Nuiqsut, permafrost, ice wedge, river dredging, gravel, construction pads

RÉSUMÉ. Au cours des 25 dernières années, le développement économique et social dans le nord de l'Alaska a crée une forte demande pour le sable et le gravier. Bien que cette ressource soit accessible sur quelques plages, lits de cours d'eau, îles-barrières, crêtes de plage et cônes alluviaux, une exploitation superficielle aboutit souvent à modifier l'environnement de façon non souhaitable dans ce milieu dominé par le pergélisol, ce qui a amené des restrictions concernant l'extraction.

En 1981, pour la première fois, le sable et le gravier ont été transférés directement de la zone du talweg d'un cours d'eau à la surface de la toundra par une drague suceuse transportable. Cela s'est passé à Nuiqsut, dains le delta de la rivière Colville en Alaska. Les $400000 \mathrm{~m}^{3}$ de sable et de gravier extraits ont suffi à construire une piste d'atterrissage et à créer une réserve pour le village.

On a utilisé ce procédé dans deux autres rivières (la Meade et la Kokolik), trois étangs côtiers (Wainwright, Kaktovik et Barrow) et deux lacs (Atqasuk et Barrow). L'établissement de profils durant 1989 a révélé que le remblayage des chenaux dragués est un processus variable. Mots clés : Alaska, North Slope Borough, rivière Colville, Nuiqsut, pergélisol, fente de glace, drague fluviale, gravier, matériau de remblai

Traduit pour Arctic par Nésida Loyer.
\end{abstract}

\section{INTRODUCTION}

The development of the petroleum industry in arctic Alaska since the late 1960s and an even more recent surge in the modernization of the villages of the North Slope Borough (NSB) have created great demands for sand and gravel. By the spring of 1980, the Public Works Department (PWD) of the NSB was planning and designing a number of capital improvement projects (CIPs) (NSB, 1986), including the construction of airports, road systems, and pads for supporting village buildings (school houses, water tanks, fire stations, and homes) in a permafrost environment.

Geologic exploration by the NSB in the vicinity of the villages (Fig. 1) showed that, with the exceptions of Anaktuvuk Pass and Point Hope, sources of surficial gravel were limited to small amounts on beaches and river bars. Although these sources had been utilized in earlier construction projects (such as for runways and roads at Barrow and Wainwright in the 1960s and for drilling pads and roads in the Prudhoe Bay area [Rawlinson, 1983]), state and federal regulations enacted in the 1970 s severely restricted the mining of such deposits.

After exhausting other options, such as the transport of sand and gravel either by barge or over winter haul roads, NSB engineers investigated the possibility of utilizing dredges in rivers that flowed near three of the villages and in lagoons and lakes adjacent to three others. A feasibility study by the NSB (Len Nelson, pers. comm. 1981) showed that the method was practical, and subsequent exploratory drilling located dredgable sources of gravel and sand (LaVielle et al., 1983). The dredging program was begun in 1981 .
Because of concern for the maintenance of the integrity of the environment, the NSB decided to conduct an environmental monitoring program throughout the dredging operation and to maintain it once dredging and construction were completed.

\section{ENVIRONMENTAL CHARACTERISTICS}

The six villages where dredging was eventually utilized (Fig. 1) are all located on the Gubik Formation of the Arctic Coastal Plain (Black, 1964). Gubik deposits consist of poorly sorted silts, sands, and gravels, which are generally of marine origin. The entire area is underlain by permafrost, except beneath the deeper (more than $2 \mathrm{~m}$ ) water bodies. Rivers, lakes, lagoons, and nearshore ocean water with such depths do not freeze to the bottom and are directly underlain by nonfrozen beds (Lachenbruch, 1968). Such occurrence allows for summer dredging that is little different from that in other climates.

The tundra upon which runways, roadways, and villages are built is susceptible to serious damage if disturbed. Surface transport can destroy the tundra vegetation, which aggravates permafrost degradation. Scars created by such activity may last for decades (Lawson, 1986). Thus, surface transport is best confined to winter roads prepared on the hard snow surface or on properly prepared raised roadbeds (Linell and Johnston, 1973).

One way to minimize damage to the tundra is to transfer the mined material directly to the surface where needed. This procedure eliminates the need for more traditional methods of transfer by haul-roads, loaders, and dump trucks (LaVielle 


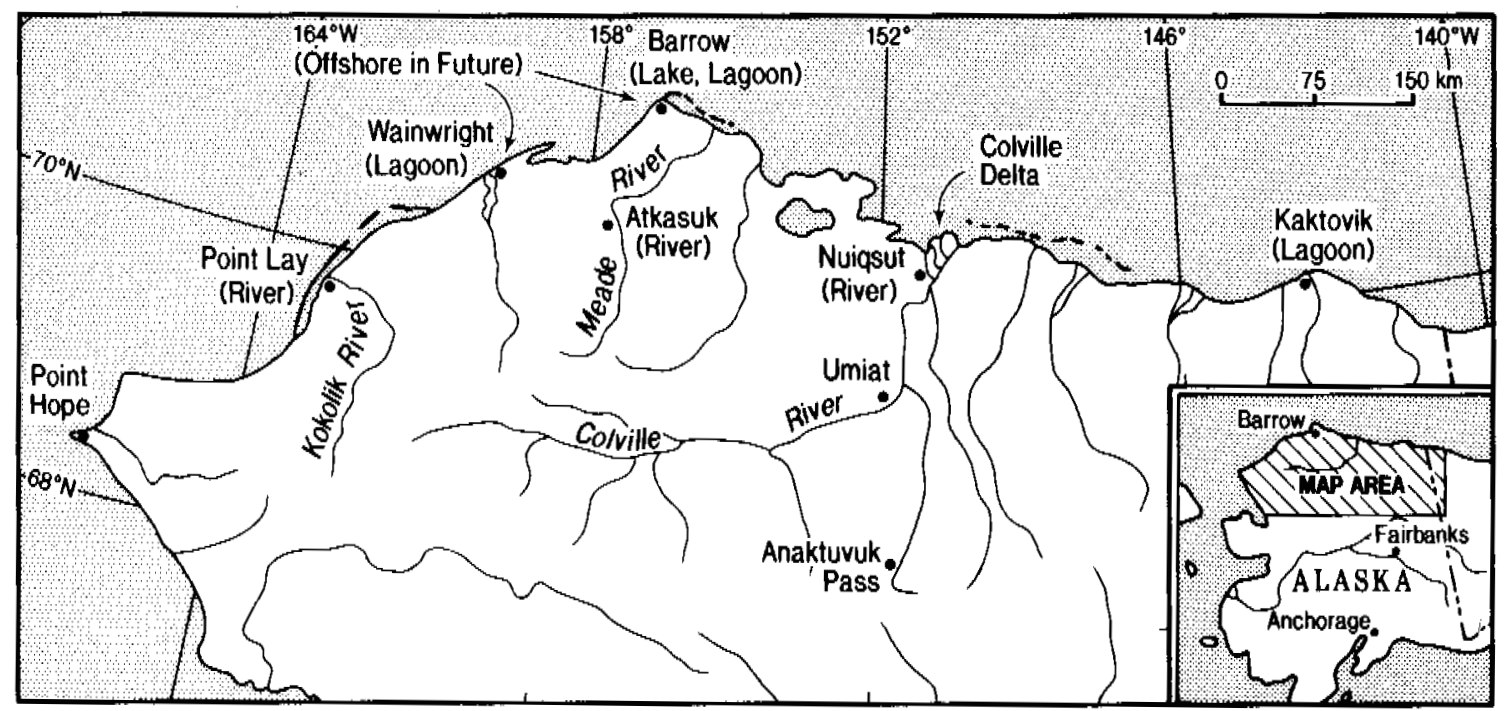

FIG. 1. Map of the North Slope Borough showing Inuit villages and dredging locations.

et al., 1983). If the source region is sufficiently close to the disposal site, transfer can be achieved entirely by piping from waterborne dredges.

Many environmental conditions - including thinness of the active layer (the surface layer that alternately thaws and freezes each year), low surface gradients, and irregular surfaces - impact construction (Gold and Lachenbruch, 1973). In addition, the upper layers of the tundra contain various types of ice bodies, including ice wedges. Where wedges occur, the surface displays irregularities in the form of ice-wedge polygons (Fig. 2). In some areas wedges occupy as much as $30 \%$ of the upper $5 \mathrm{~m}$ of the soil. Because their continued existence depends upon year-round persistence of temperatures below $0^{\circ} \mathrm{C}$, any disturbance that subjects them to thaw causes subsidence and further disruption of the surface. Destruction of the insulation properties of the overlying tundra mat by removal, improper construction, or changing the water regime will lead to ice wedge degradation (Mackay, 1970; Walker, 1986). Unless construction pads are sufficient to protect the underlying permafrost and its included ice, slumping in the pad will occur, which in turn may damage any structures that had been placed on it.

\section{THE DREDGE PROGRAM}

\section{Design and Logistics}

The climatic, geomorphic, and hydrologic nature of arctic Alaska and the relative inaccessibility of job sites placed severe restrictions on dredge design. The dredges were broken into mòdules for transport by C-130 Hercules aircraft. Spuds were made to be self-erecting because of the unavailability of cranes and other heavy equipment in the field. Flotation sponsons were built in two sections and included fuel cells and spare part storage bins.

In addition to the dredge itself, all support equipment had to be built and purchased with the remote location in mind. High-density polyethylene discharge pipe was used instead of steel in order to avoid the need for pipe floats. Fuel barges, anchor scows, and tenders were built with mobilization problems in mind. Although the equipment was transported to the North Slope by aircraft, it was moved from site to site during winter by "cat train."

Because the dredging season (the period when rivers, lakes, and lagoons are ice free) is only about 90 days, all mobilization and assembly had to be completed prior to breakup. Dredging is a 24-hour operation, which is facilitated by continuous daylight.

\section{Dredge History}

The dredging program was initiated in 1981 on the Nechelic Channel of the Colville River near Nuiqsut (Fig. 3), one of the new (1973) villages established by the NSB. The primary objective of dredging at this location was to obtain gravel for the purpose of building a $1550 \mathrm{~m}$, year-round airstrip above the floodplain.

The location selected for dredging is upstream from a long bend in the river where water depths during normal summer stage range from 3.0 to $5.5 \mathrm{~m}$. The dredging operation at Nuiqsut occupied two summers (1981 and 1982). During the first summer more than $150000 \mathrm{~m}^{3}$ of sand and gravel was pumped from the dredge through a $46 \mathrm{~cm}$ polyethylene pipe a distance of up to $3 \mathrm{~km}$ and placed directly on the tundra surface to form the runway. During 1982 another $250000 \mathrm{~m}^{3}$ of material was stockpiled adjacent to the river for later use in other Nuiqsut construction projects (Fig. 4).

In order to maintain the integrity of the tundra surface adjacent to the runway, the water that carried the material through the pipe was collected in the middle of the runway and then pumped back into the river so that it would not have to flow over the tundra surface.

The success of the 1981 operation at Nuiqsut resulted in projects at other villages. In 1982 dredging was begun near Wainwright (Fig. 1), where some $300000 \mathrm{~m}^{3}$ of gravel was stockpiled. During winter 1982-83, the "Nivakti" (the dredge used in Nuiqsut) was moved to the Meade River near Atqasuk (Fig. 1). In its first season there nearly $90000 \mathrm{~m}^{3}$ of 


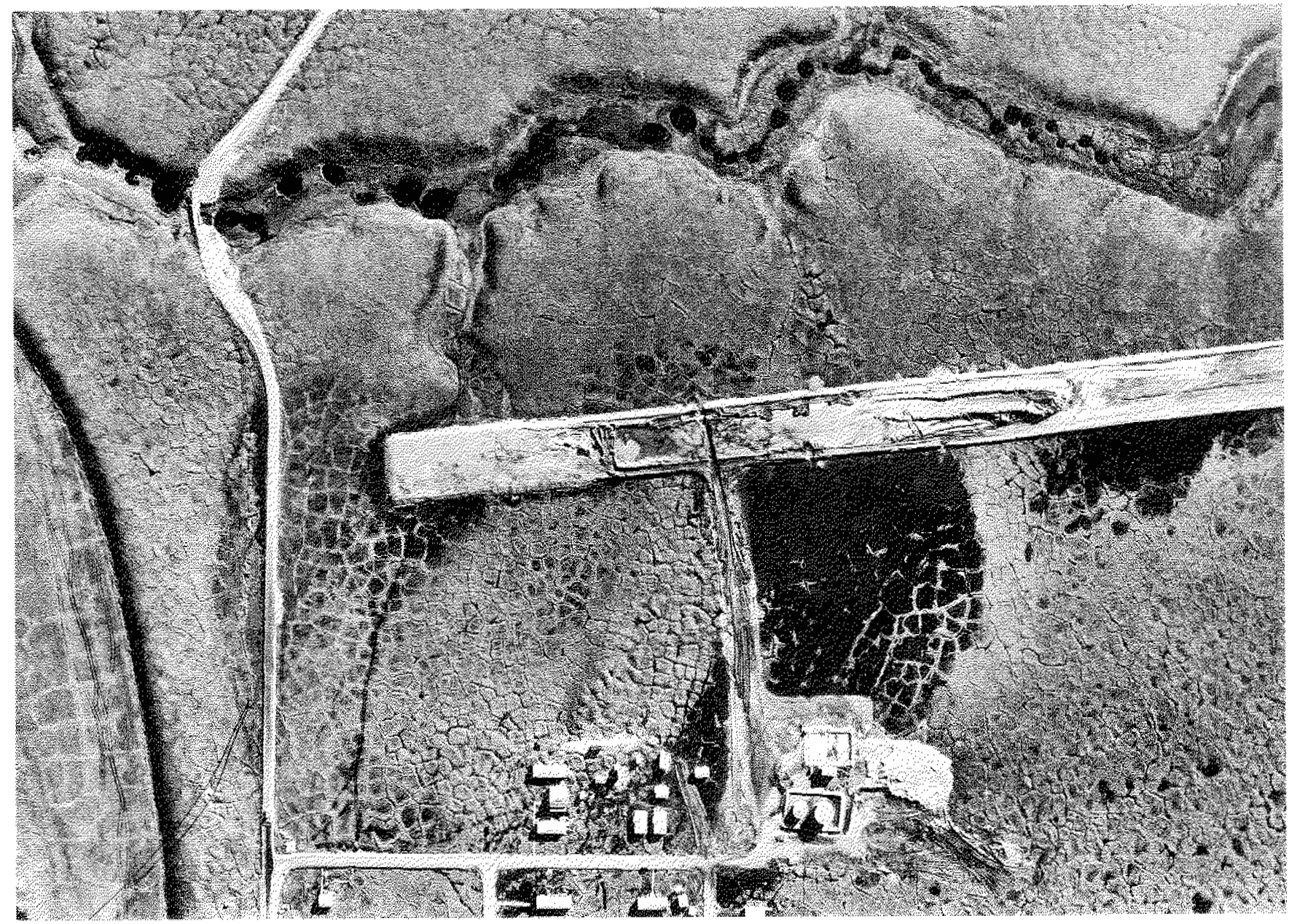

1ik; 2. The Nuigut runway under construction. Note the ice-wedge polygons that surtound it and the ponded water between the taxi strip and the runway. The photo is located at Area A on Figure 3 .

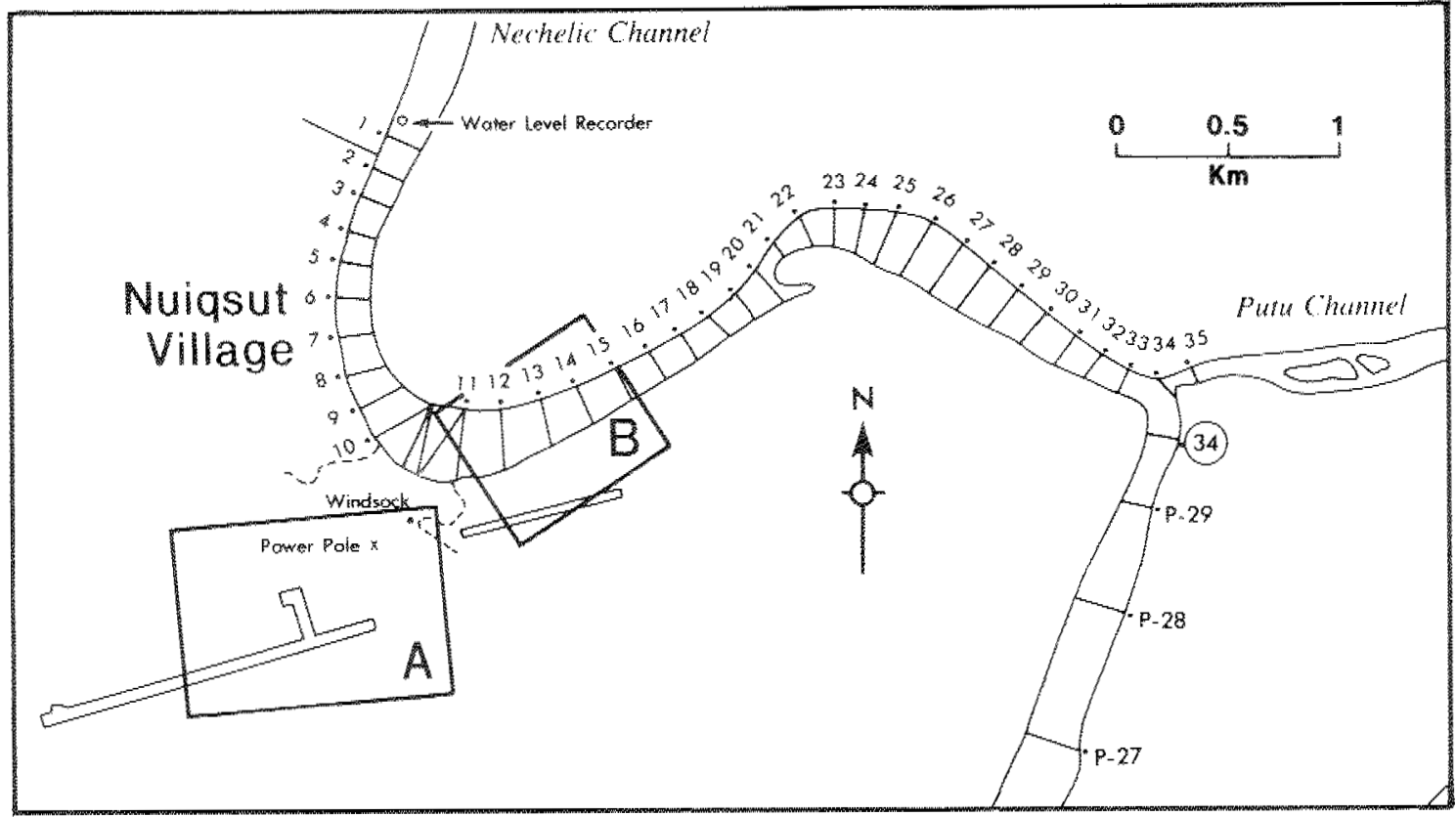

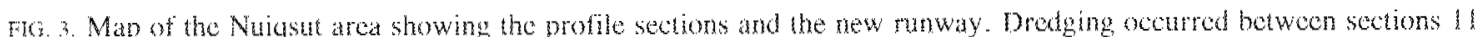
and 14. Area A is shown in Figure 2 and Atea $B$ is shown in Figure 4. 


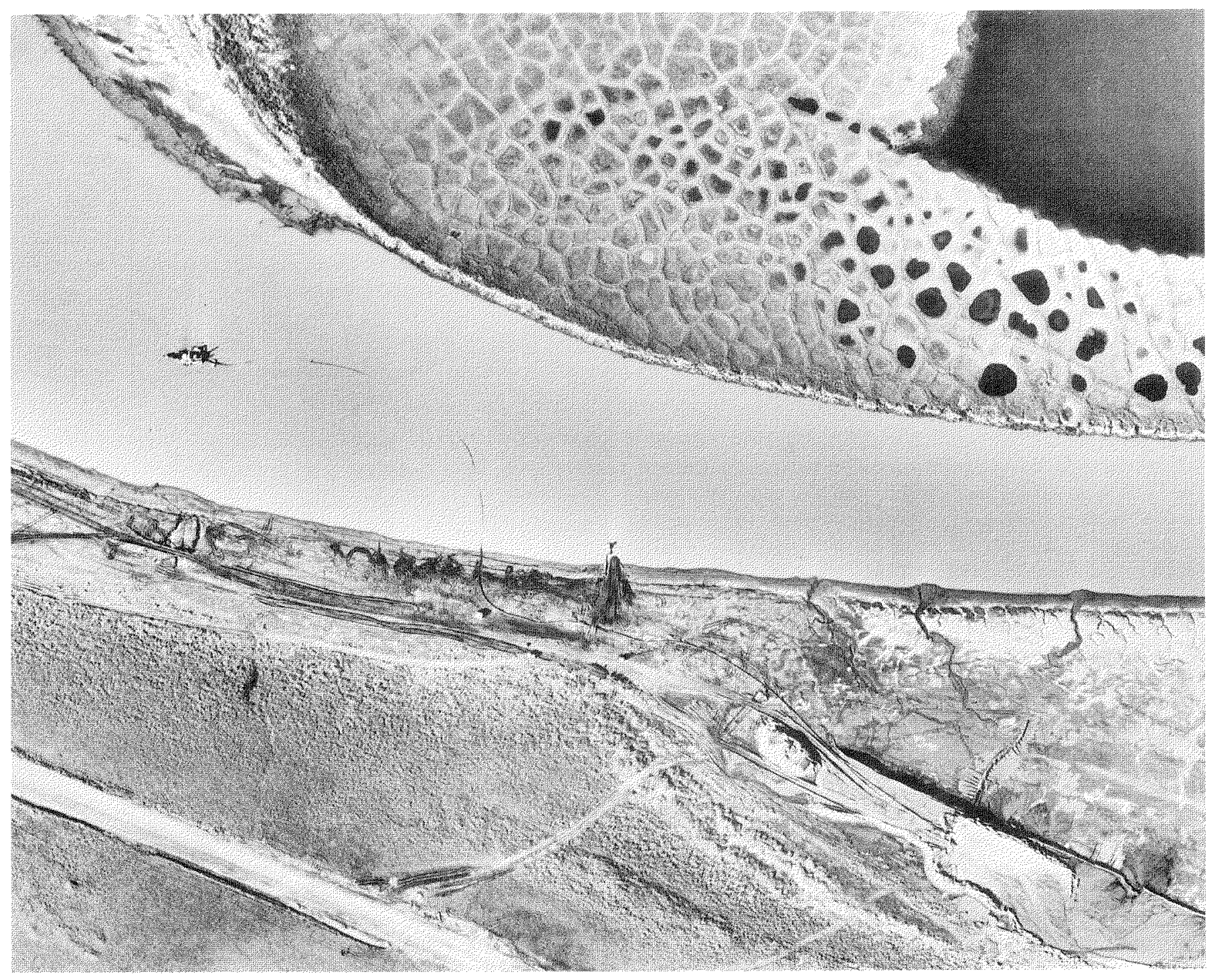

Fo. 4. The dredge in operation at Nuiqsut. Note the polyethylene pipe floating on the river and the construction of a stockpile. The photo is located at Area $B$ on Figure 3

crushable river gravels was stockpiled. During winter it was moved to Immaqruaq Lake, a large lake just west of the village. In 1984 dredging in the lake produced nearly $350000 \mathrm{~m}^{3}$ of sand, which was used in making a road to the airport site and in constructing containment dikes around it. Then, in 1985, further dredging in the lake produced $175000 \mathrm{~m}^{3}$ of sand, which was piped to the diked area to form the runway. The 1983 gravel, which had been stockpiled near the river at Atqasuk, was crushed and used to upgrade the road to the airport, the runway, taxiway, and apron (NSB, 1986).

Dredging was initiated in the lagoon at Kaktovik (Fig. 1) in 1983. During two seasons, $130000 \mathrm{~m}^{3}$ of gravel was stockpiled for various village uses. Because the stockpile was on the spit side of the lagoon, it was hauled during winter over lagoon ice to its destination.

In 1984 dredging in the Kokolik River produced $230000 \mathrm{~m}^{3}$ of sand and gravel, which was stockpiled near the river about $2.5 \mathrm{~km}$ from the village of Point Lay (Fig. 1).
It was used for a variety of village projects and, because of the environmentally sound gravel road that leads to it, it was available year-round. The stockpiled gravel was depleted in 1989 in the process of upgrading and enlarging the road system at Point Lay. In 1993 additional dredging in the Kokolik River renewed the stockpile.

At Barrow (Fig. 1), a dredge operated each summer between 1983 and 1988 for a variety of purposes, including the deepening of both the water supply lagoon and sewage disposal lagoon and in renovating lagoon dams and beaches.

North Slope dredging has now been employed in three rivers, three lagoons, and two lakes. The dredged materials were transferred directly to the job sites or stockpiled for future use. Some of the gravel was crushed for use in capping runways and other surfaces. Although the prime objective in several instances was to produce material for runway construction, in almost all cases additional material was stockpiled for village use. 


\section{ENVIRONMENTAL IMPACTS}

Because of the pioneering nature of the effort to obtain large quantities of material in an arctic environment, the NSB built into its program provisions for monitoring environmental changes that would occur during and subsequent to the dredging operations. Baseline studies were made of the rivers before dredging and of the tundra surface prior to the direct placement of dredged material upon it. Subsequent to project completion, monitoring of environmental changes, especially of river channels, has been a continuing program (Walker, 1982, 1983, 1985, 1988, 1990; Walker and Roselle, 1984).

\section{Dredge Channels}

The Nechelic Channel: Although the earliest profiles made in the Nechelic Channel date from 1962 (Arnborg et al., 1966), closely spaced sections were not established until 1981, when dredging was initiated. Sixteen permanent stations, $30 \mathrm{~m}$ apart, were staked out just upstream from Nuiqsut on the right bank adjacent to the part of the channel to be dredged. Between 1981 and 1989 cross-section profiles were made during six different years (Figs. 5,6). The stage of the river, which varied by as much as $1.2 \mathrm{~m}$ during the six seasons, was determined from a benchmark located on the bluff near Nuiqsut (Fig. 7).

The first two years (1981 and 1982) of dredging nearly tripled the depth of the thalweg, as is shown on the map for
June 1983 (Fig. 5). Because dredging continued after the time profiling was done in 1982 , the greatest depths recorded are those for 1983. Although there may have been some fill during the breakup of 1983 , it apparently was minimal. By 1985 channel fill was quite measurable in the middle section of the dredged area. However, erosion deepened the channel in an upstream direction. Because dredging increases the gradient of the riverbed, such upstream erosion is typical of dredged channels (Galay, 1983). By 1987 all dredged sections were filling. The fill by 1989 , which totaled $171000 \mathrm{~m}^{3}$, had progressed to such an extent that the thalweg reached $10 \mathrm{~m}$ in depth at only one location (Fig. 5). This fill represents over $40 \%$ of the total dredged seven years earlier. Fill has been more rapid on the point bar side of the channel than on the outside of the meander. Thus, the thalweg established by dredging is being shifted toward the left bank (Fig. 6: sections 13 to 13.2).

The Colville River has a highly variable discharge, as do all rivers in arctic Alaska. During winter, discharge is zero; however, during the flood period, it can reach quantities exceeding $6000 \mathrm{~m}^{3} / \mathrm{s}$. It is also during pre-breakup, breakup, and post-breakup flooding that most of the river's water and sediment are transported seaward. About one-fifth of both water and sediment of the Colville River is diverted through the Nechelic Channel, with some $75 \%$ of it being carried during a 2- to 3-week period (Arnborg et al., 1967). The channel contains pockets of gravel and coarse sands and even

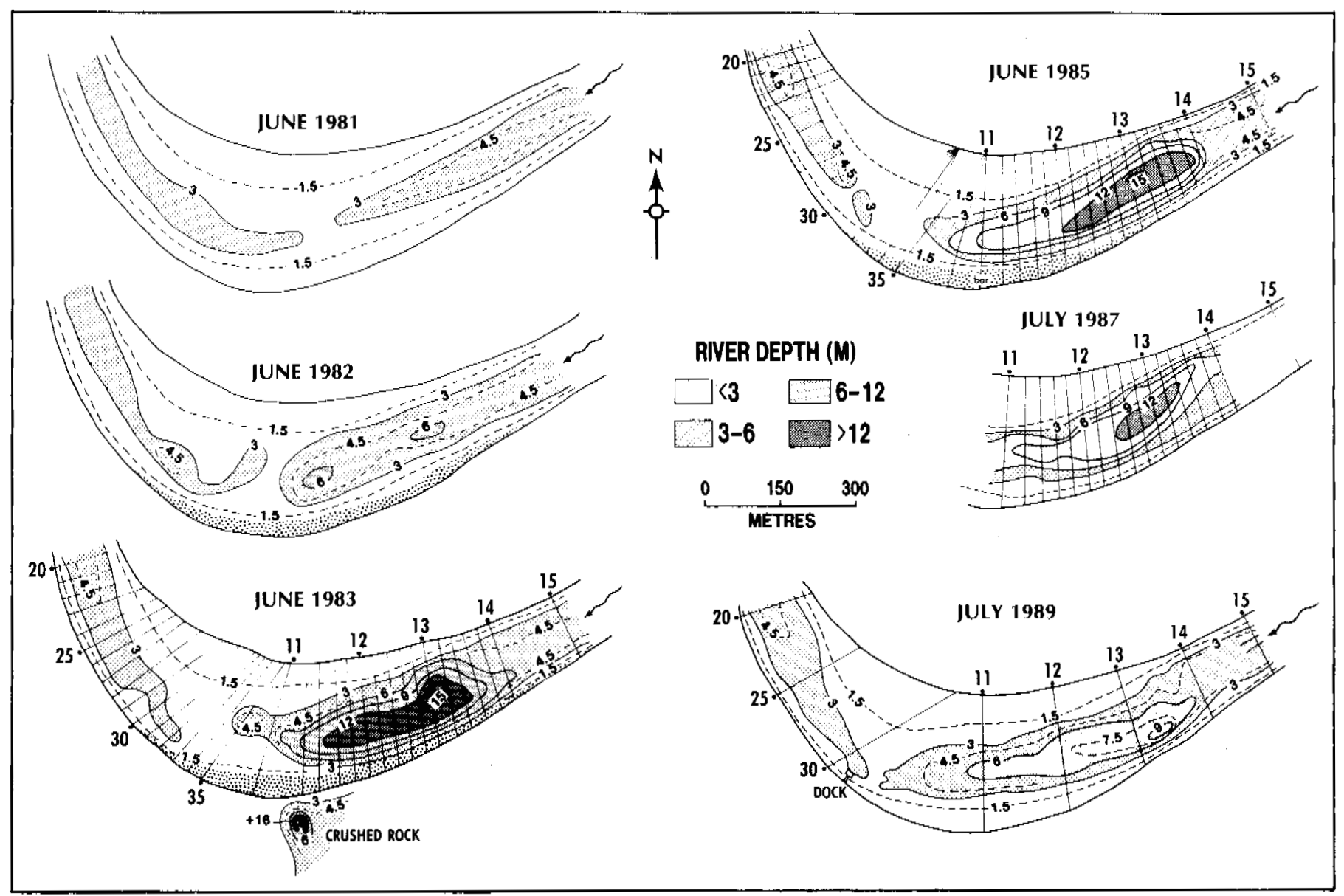

FIG. 5. Maps showing the changes in the dredged reach in Nechelic Channel. 


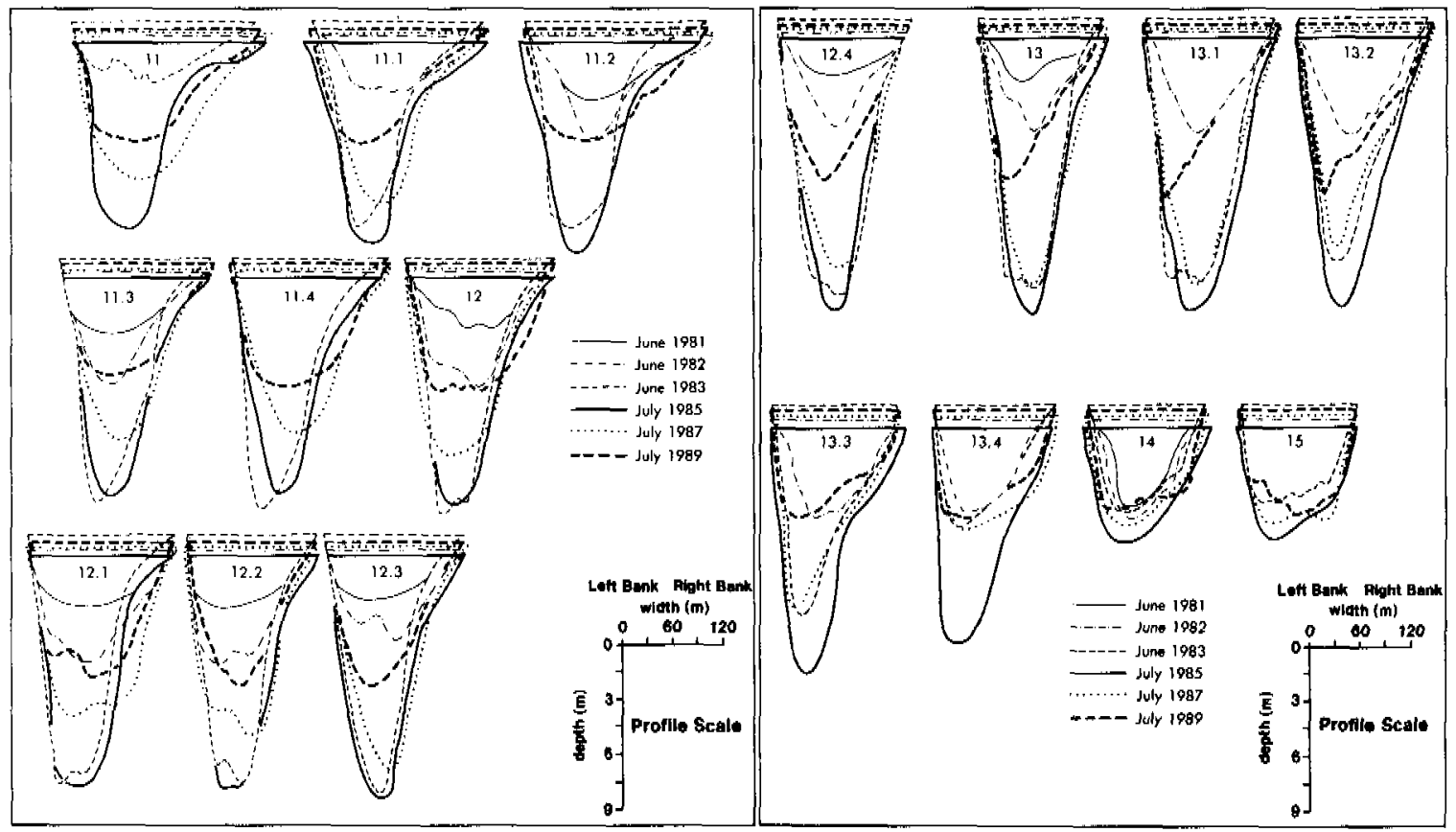

FIG. 6. Nechelic cross-section profiles 11-15, 1981-89.

fossil materials, such that the material dredged from the channel was somewhat coarser on the average than that being deposited in it today. The sediment being deposited, as calculated from grab-bucket samples, is about evenly divided between silt and sand. Very little clay and gravel is presently being added to the trench.

The right bank of the Nechelic Channel adjacent to the dredge channel is composed of peat and has a slow rate of retreat. In contrast the cutbank downstream of Nuiqsut, which is composed of Gubik materials, has a highly variable rate of retreat (Walker et al., 1987). Data collected on erosion rates of these banks do not show that dredging has been responsible for rate changes (Walker, 1990).

In addition to changes in channel morphology, dredging resulted indirectly in another modification. During dredging, fine materials, either stirred up during the dredging operation or returned to the channel during dewatering of the runway surface, were deposited in the river (Fig. 8). The small delta

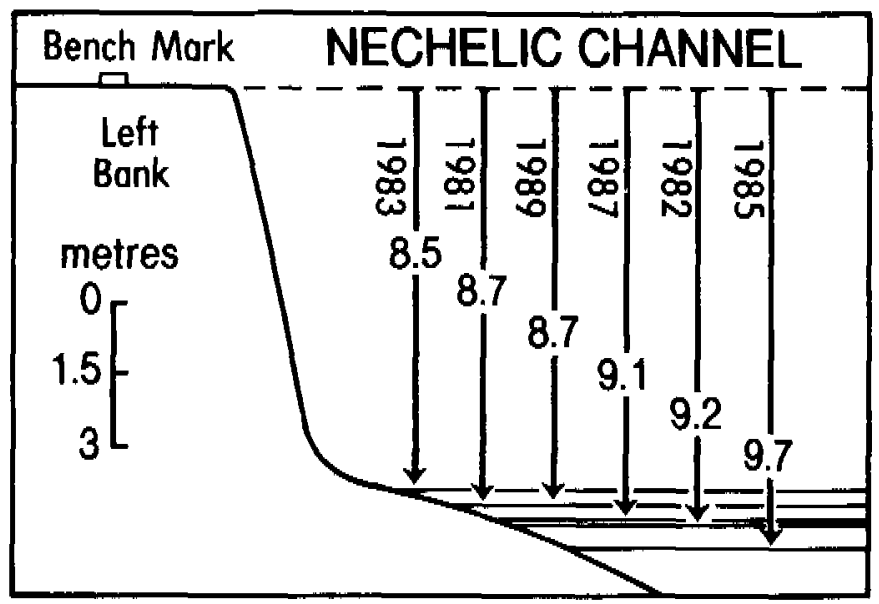

FIG. 7. Stage variations in the Nechelic Channel during echosounding. created at the dewatering outlet was a conspicuous feature for two years. However, with normal channel flow and breakup ice scour, this small, artificially created delta was removed rapidly, with nearly all evidence of it being gone by 1987 .

The Meade River and Kokolik River: The procedures used on the Nechelic Channel were also used in monitoring the dredge channels of the Meade River (at Atqasuk) and the Kokolik River (at Point Lay) during 1983, 1985, 1987, and 1989. At Atqasuk 52 cross-sections (25 across the dredge channel) and at Point Lay 33 cross-sections ( 8 across the dredge channel) were echosounded. These two rivers are smaller than the Nechelic and have lower discharges. The Meade River near Atqasuk averages only $150 \mathrm{~m}$ in width, with a normal (post-breakup flooding) depth of about $3 \mathrm{~m}$. The Kokolik River, in contrast, is variable in width (120-250 m) and in depth (2-4 m) along the dredge section. In the dredged area the Meade River was deepened by as much as $4 \mathrm{~m}$, whereas the Kokolik River was deepened between 4.5 and $5.5 \mathrm{~m}$.

They also differ from the Nechelic in the nature of their bed materials. The Meade is composed of very coarse-grained sediments, including boulders, and has a bed that is rough. Even after six years the dredged bed was still rough and fill was minimal. The Kokolik dredge site is near the river's mouth and has much finer sediments than the Meade River, even somewhat finer than Nechelic Channel. The Kokolik dredge channel is filling up at a slower rate than the Nechelic because of its small load and finer textures, which in turn allow higher percentages of sediment to be carried in suspension past the trench.

\section{The Tundra}

The eventual disposition of virtually all of the dredged material is on the tundra surface as roads, runways, and 


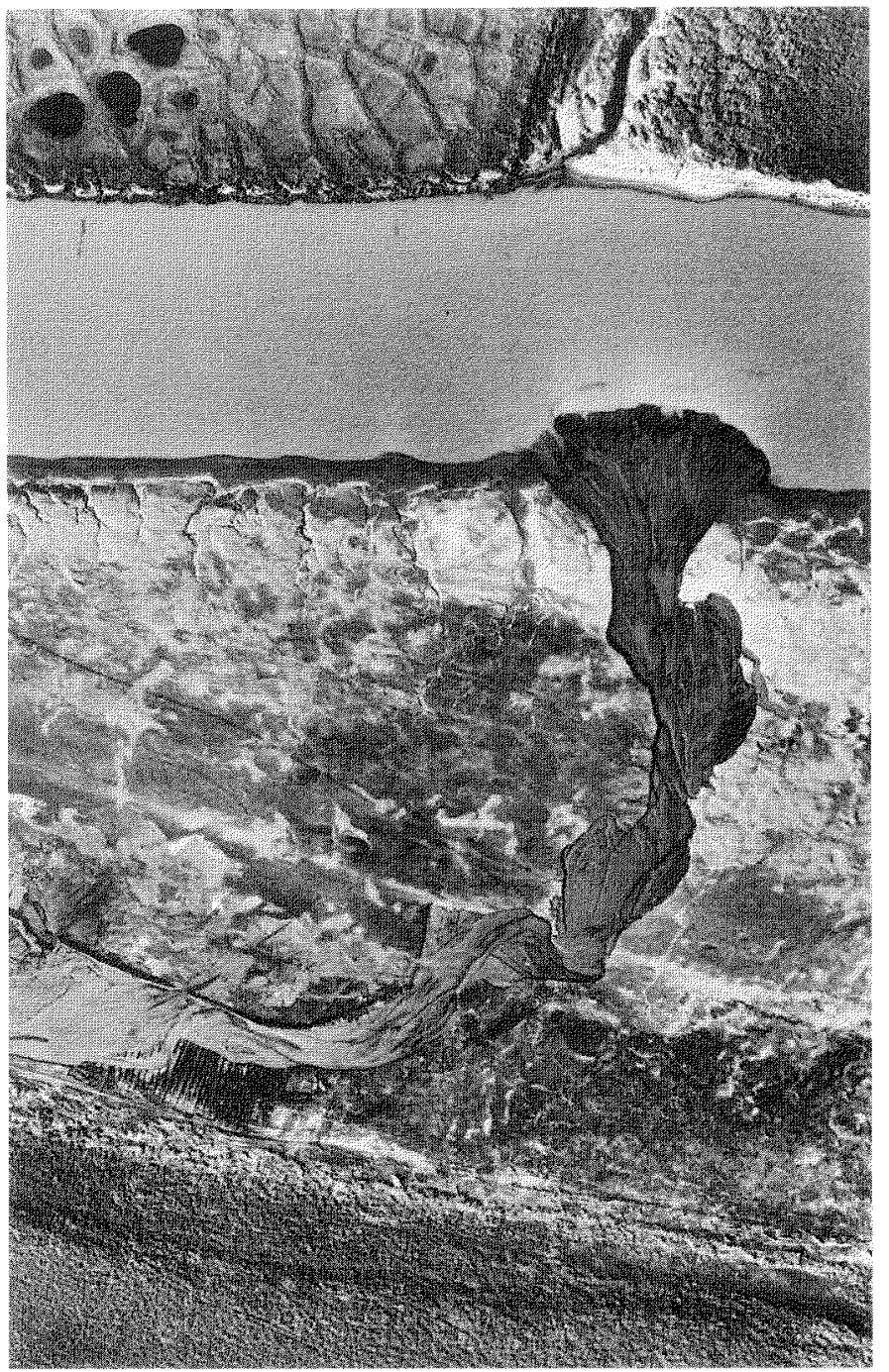

Fls. \&. Fine sediments being deposited in the river during the dewatering process in runway and stockpile formation.

building pads. In order to protect the thermal regime of the permafrost and thus eliminate differential thaw and subsidence, the pads are made 1-2 m thick and in some cases underlain by protective fabric (Fig. 9).

Before placement directly on the tundra surface for runways, containment berms were built outlining them (Figs. 2, 10). In this way dredged materials, including the water piped in, could be controlled and contained so that the tundra outside the runway itself remained undisturbed. Prior to construction at Nuiqsut, a detailed map of the runway area was prepared showing locations of ice wedges and other surface features (Fig. 10). Although the tundra was relatively flat, local relief was variable such that the runway fill was of different thicknesses along it. The most important natural phenomenon that could affect runway stability is the ice wedge. Along the course of the Nuiqsut runway ice wedges occurred at about $12-15 \mathrm{~m}$ intervals and were randomly oriented (Fig. 10).

In addition to the general survey, detailed cross-sections were made at five locations across the runway. Along each section, relief, active layer development, standing water, and vegetation types were mapped. The active layer averaged only about $15 \mathrm{~cm}$ at the time of the survey (10 June 1981). The cross-sections served as a base for measurements during construction. Throughout the summer the active layer increased to an average of about $35 \mathrm{~cm}$ (Walker, 1983).

Monitoring of the runway subsequent to completion has shown no major subsidence due to ice wedge thaw beneath it. Further, because the integrity of the adjacent surface was protected (it was off limits to tractors or other vehicles), subsequent years have shown no changes on the tundra surface - with one exception. Because the runway and its taxi strip have created a dam, a small body of standing water developed at the junction of the taxiway and runway (Fig. 2).

The success of the operation at Nuiqsut led to an expansion of the program to other locations. Environmental impacts, except at stockpile locations, have been minimal.

\section{THE FUTURE}

The dredging program, in the opinion of NSB officials, is "... an unqualified success in providing the gravel resources required by the villages. In addition, the program has been responsible for many jobs for the local people . . ." (NSB, 1986:6). Further, it has proven to be environmentally sound in that the integrity of the tundra has been maintained and over-wintering areas for fish in the rivers and lakes have been deepened and enlarged. There is no indication that the dredging has adversely affected the fish populations in the rivers (Larry Molten, pers. comm. 1993).

In 1986 two severe storms caused extensive beach erosion at Barrow and Wainwright (Walker, 1991). Subsequently various protection procedures have been investigated. In 1990 plans were drafted to extend the dredging program offshore (Fig. 1) in order to acquire material for replenishing beaches. In 1993 a special barge was being fabricated to use in the offshore dredging program that is slated to begin in 1994 (Len Nelson, pers. comm. 1993). At both Barrow and Wainwright beach mining in the 1950 s and 1960 s reduced beach size and thickness and probably aggravated bluff erosion. It is believed that replenishing the beaches will help reduce such erosion in the case of future storms.

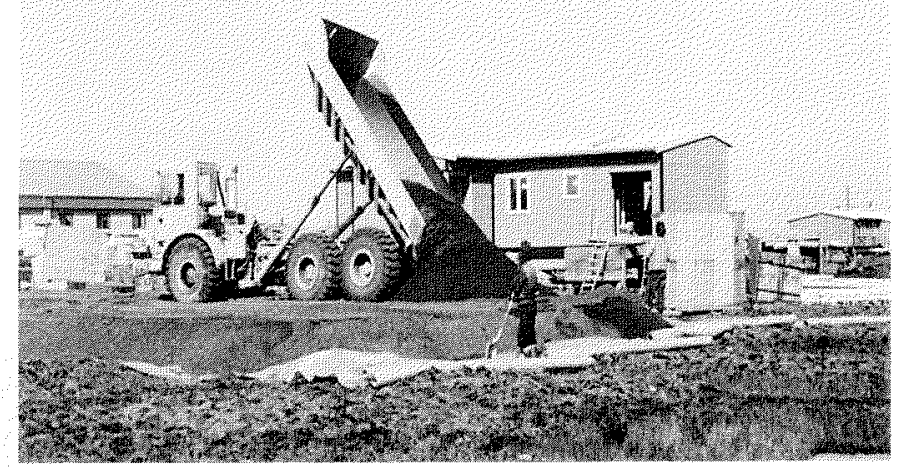

FIG. 9. Gravel pad being constructed at Nuiqsut. Note the protective fabric to the right of the pad. 


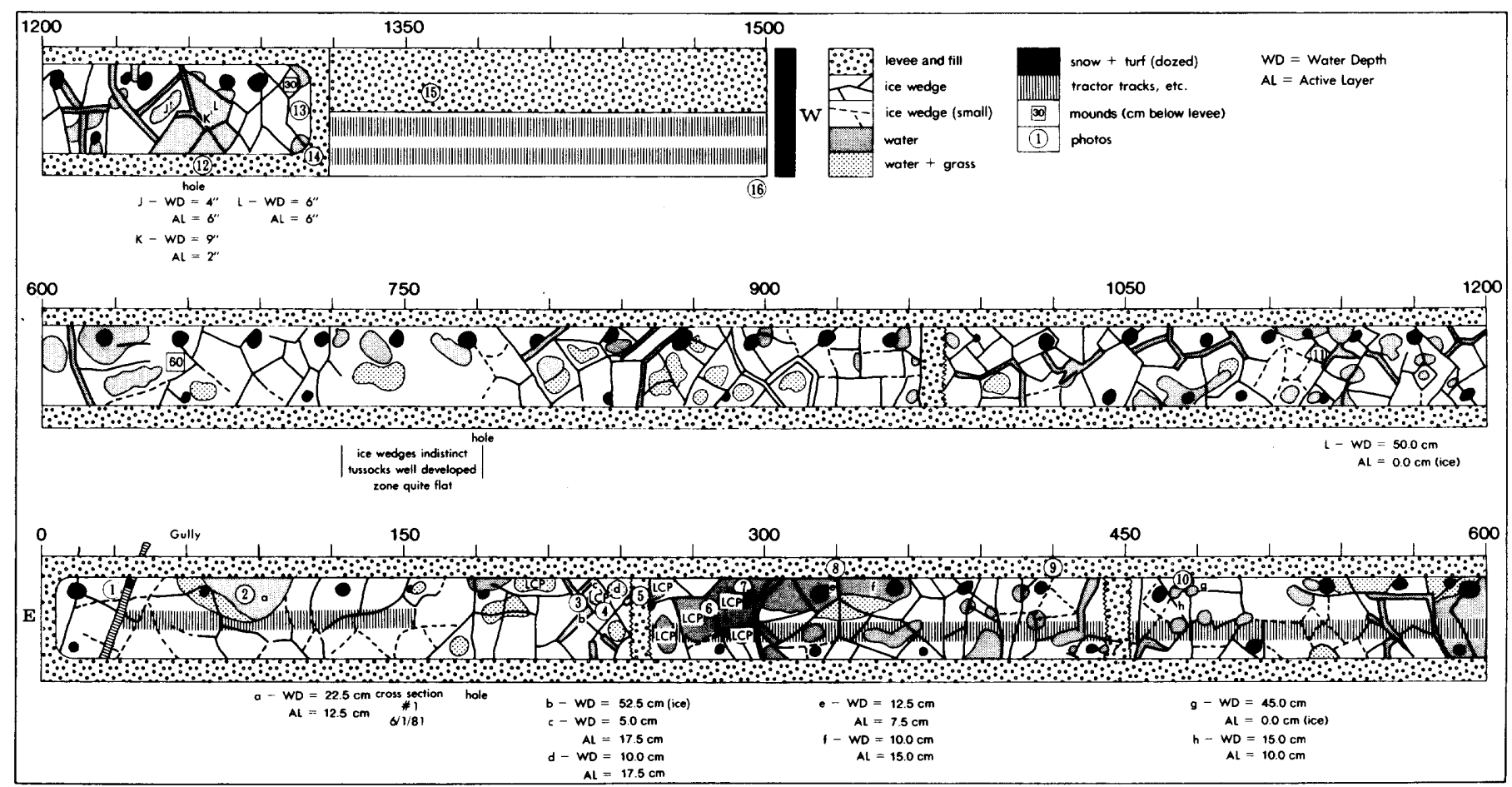

FIG. 10. Map detailing the characteristics of the tundra surface of the runway prior to fill being added.

\section{ACKNOWLEDGEMENTS}

The fieldwork upon which this paper is based was supported by the North Slope Borough, Alaska. The assistance of Edward Itta, Mike Weston, and Len Nelson and suggestions made by anonymous reviewers are greatly appreciated.

\section{REFERENCES}

ARNBORG, L., WALKER, H., and PEIPPO, J. 1966. Water discharge in the Colville River, 1962. Geografiska Annaler, Series A, 48:195-210.

ARNBORG, L., WALKER, H., and PEIPPO, J. 1967. Suspended load in the Colville River, Alaska, 1962. Geografiska Annaler, Series A, 49:131-144.

BLACK, R.F. 1964. Gubik formation of Quaternary age in northern Alaska. U.S. Geological Survey Professional Paper 302-C:59-91.

GALAY, V.J. 1983. Causes of river bed degradation. Water Resources Research 19:1057-1090.

GOLD, L.W., and LACHENBRUCH, A.H. 1973. Thermal conditions in permafrost - A review of North American literature. In: North American Contribution Permafrost Second International Conference, National Academy of Sciences, Washington, D.C. 3-25.

LACHENBRUCH, A.H. 1968. Permafrost. In: Fairbridge, R.W., ed. Encyclopedia of geomorphology. New York: Reinhold. 833-839.

LaVIELLE, C.C., GLADDEN, S.E., and ZEMAN, A.R. 1983. Nuiqsut airport dredge project. Proceedings, Fourth International Conference on Permafrost, National Academy Press, Washington, D.C. 689-694.
LAWSON, D.E. 1986. Response of permafrost terrain to disturbance: A synthesis of observations from northern Alaska, U.S.A. Arctic and Alpine Research 18:1-17.

LINELL, K.A., and JOHNSTON, G.H. 1973. Engineering design and construction in permafrost regions: A review. In: North American Contribution Permafrost Second International Conference, National Academy of Sciences, Washington, D.C. 553-575.

MACKAY, J.R. 1970. Disturbances to the tundra and forest tundra environment of the western Arctic. Canadian Geotechnical Journal 7:420-432.

NORTH SLOPE BOROUGH. 1986. Material dredging program. Barrow: North Slope Borough. 6 p.

RAWLINSON, S.E. 1983. Guidebook to permafrost and related features, Prudhoe Bay, Alaska. Fairbanks: Division of Geological and Geophysical Surveys, Department of Natural Resources. $177 \mathrm{p}$.

WALKER, H.J. 1982, 1983, 1985, 1988, 1990. North Slope Borough river and coastal investigations, Reports. 33 p., 58 p., 56 p., 57 p., 50 p. respectively. Available at CIPM, North Slope Borough, Box 350, Barrow, Alaska 99723.

1986. Periglacial environments. In: Fookes, P.G., and Vaughan, P.R., eds. A handbook of engineering geomorphology. New York: Chapman and Hall. 82-96.

1991. Bluff erosion at Barrow and Wainwright, arctic Alaska. Zeitschrift für Geomorphologie, Supplement Vol. 81:53-61.

WALKER, H.J., and ROSELLE, D. 1984. The Nuiqsut, Atqasuk, and Point Lay dredge channels. North Slope Borough Report. 42 p. Available at CIPM, North Slope Borough, Box 350, Barrow, Alaska 99723.

WALKER, H., ARNBORG, L., and PEIPPO, J. 1987. Riverbank erosion in the Colville River delta, Alaska. Geografiska Annaler, Series A, 69:61-70. 